\title{
A southern perspective on development studies: contributions from Latin America
}

\author{
UNA PERSPECTIVA DESDE EL SUR SOBRE LOS ESTUDIOS DEL DESARROLLO: UNA CONTRIBUCIÓN DESDE \\ LATINOAMÉRICA
}

Carlos Mallorquin (carlosmallorquin1@gmail.com) Autonomus University of Zacatecas (Zacatecas, Mexico) ORCID: 0000-0001-7195-8775

\begin{abstract}
The article offers a synthesis of Latin American economic thought post-second world war, underlining in particular the specificity of the regional perspective. The idea is to describe their beginnings and key regional authors, which is generally unknown in Anglo-Saxon academic circles. The reading that guides the presentation questions Eurocentric interpretations. Since the 1980 economic discourse in Latin America has lost its sui generis characteristics, its vocabulary today has been lost to the new generations, given the pre-eminence of orthodox neoliberal ideas and policies which certainly have not improved the living standards of the region.
\end{abstract}

Key words: development, Latin American structuralism, Furtado, Prebisch, import substitution industrialization.

\section{Resumen}

El artículo ofrece una síntesis de pensamiento económico de América Latina después de la segunda guerra mundial, desarrollando en particular la especificidad de la perspectiva regional. La idea es describir sus comienzos y sus autores claves, los cuales generalmente son desconocidos en los círculos académicos anglosajones. La lectura que guía la presentación cuestiona las interpretaciones eurocéntricas. Desde 1980 el discurso económico en América Latina ha perdido sus características sui generis. Su vocabulario hoy se ha perdido para las nuevas generaciones, dada la pre-eminencia de las ideas de la ortodoxia neoliberal y sus políticas, las cuales ciertamente no han mejorado los estándares de la vida en la región.

Palabras clave: desarrollo, estructuralismo latinoamericano, Furtado, Prebish, sustitución de importaciones.

\section{Introduction}

"Economic science is universal, like mathematics. Economic science is not pampa, guarani or tehuelche. If its applicable in Europe, in America too" (Caravaca 2011:35).

As the epigraph goes, in the last decade of the 19th century, the congress in Argentina witnessed the then Minister of the Economy defending the idea that the government applied policies sustained by principles of universal validity. The political confrontation brought to light the notion that perhaps those "knowledge's" coming from afar, are not as consistent as they make out to be, and that local theorization's 
were necessary to "discipline" the "science" in question. The following article stresses the idea that a relatively autochthonous discourse on development was constructed in the Latin American region, which can be defined as the "centre-periphery" perspective initially developed by Raúl Prebisch. Ultimately it's a perspective which examines the power asymmetries that underline social relations, within and between regions, and countries, therefore the centre-periphery couple, is not necessarily a "geographical" peculiarity; it denotes some mechanism of exclusion and/or exploitation, within and between communities. At the (exchange) knowledge continuum the conception of power asymmetries can be made to look similar to Connell's idea of a "southern theory". We generalize Connell's notion of the "colonial" asymmetries: "Knowledge about a colonized society is acquired by an author from the metropole and deployed in a metropolitan debate. Debates among the colonized are ignored, the intellectuals of colonized societies are unreferenced, and social process is analysed in an ethnographic time-warp" (Connell 2007:44).

The rise of the "discursive formation" (Foucault) in question first entailed a deconstruction-reconstruction of what was accepted as social science (economics, sociology, political theory, anthropology) in the AngloSaxon universities, or in short, the "Eurocentric" vision of the world. In other words, it required a decolonizing conceptual strategy, creating a vocabulary not only consistent with the new "objects" which it was its purpose to explain, but also, in its aftermath showing that the theoretical inadequacies of the Eurocentric discourses were unsustainable within their own universe, within its own perspective and entities it supposedly analysed in the "north".

This aspect has to be mentioned because initially, in the post-war period, there was the belief that, economics, for example, could play, as it were, two different "scientific" games; one in which its categories where congruent and "coherent" for "developed economies", and simultaneously, another in which, certain concepts of the dominant literature in economics where "offside" given certain institutional and organizing qualities of the countries themselves: the "underdeveloped countries", admitted and required the elaboration of differing and distinct categories. This divergent evolution in their respective objects and vocabulary came abruptly to an end by the end by the early 1980 's, in institutions and countries, "centre" and "periphery" alike; it signals the hegemony of neoclassical thought.

But two decades previously, by the mid 1960's the "centre-periphery" perspective would evolve into a two intertwined stream of ideas, where some of its proponents would change theoretical camps, in more than one occasion during the following years, one was denominated Latin America Structuralism and the other the Dependency Approach. This distinction is important because the rise of neoliberalism hegemony's early in the 1980's was the product of its criticism of certain development strategies in the region, conforming a strange alliance with the dependency approach vis a vis Latin American Structuralism.

Before describing the evolution of the Latin American theoretical perspective, and some of the personalities involved, it is important to touch on certain political and institutional transformations in the aftermath of the second world war (section called It's a hard chilliness a-gonna fall), which made possible the posing of certain questions blocked hitherto and also the appearance of the Latin American discourse or the "will to power" in question. In the final section of the paper (called Under the sweltering heat of the "Washington consensus"), we try to elaborate a brief synthesis of the consequences and limitations of those policies and contest its hegemonic presence, and some descriptions of the economic and social tendencies in the region that should help focus on alternatives political strategies. 


\section{It's a hard chilliness a-gonna fall}

The political and intellectual undercurrents that drove the centre of world power after the Second World War are not recognizable today, given the relatively "multi-polar" dominion arrangements, despite United States of America's relative hegemony. Then it seemed imminent the face-to-face confrontation between the United States and the Soviet Union. The context of the Cold War after the Second World War, and the post-colonial movements of liberation led to the emergence of a host of voices from "third world" countries looking to make themselves heard on the international stage, especially at the United Nations.

The new power centre and guardian of the capitalist world, the United States of America, which had arisen from the demise of Great Britain, sought new forms with which to organize the world economy. First came the founding of new rules for the flow of trade in general. Retrospectively, the Bretton Woods arrangements on the one hand, and the Marshall Plan for Europe on the other, which were intended as the basis for the reconstruction of a war-devastated Europe, formed part of the same process. If great efforts could be undertaken to "promote higher living standards", as the UN declared, why not develop specific means to undertake its implementation? This view led to the setting up of the Economic Commission for Europe and for Asia; and it was only a matter of time before other regions started creating similar demands and projects.

Within this scenario, a well-organized group of people in Latin America, talented and confident in their specific fields and backed by their respective governments, managed to present a project for the creation of an Economic Commission for Latin America or ECLAC (later to include "the Caribbean" as Economic Commission for Latin America and the Caribbean). Their diplomatic lobbying, with the help of some of their western European counterparts was very successful, given the clear opposition to it by the United States government that had other plans: an organization, headed by it within the Organization of American States (OAS). Thus, by 1947, ECLAC had come to life for a three-year trial period, starting in 1948. It must be remembered that before ECLAC's confirmation in 1951 as part of the United Nations Organization family, the United States government hounded its existence until it was finally defeated by the alliance of the Latin American governments. One should bear in mind that it was Getulio Vargas' ultimate push that finally made it possible to set up ECLAC, contrary to the wishes of the United States.

By January 20th 1949, the countries of the region had been consigned among those "underdeveloped areas" by the inaugurating speech of the newly elected president of the United States of America, Harry S. Truman. He went on to promise help to develop those underdeveloped nations that advocated "freedom" and "liberty". A couple of months later appeared Prebisch's report to ECLAC: The Economic development of Latin America and its principal problems, hence forward becoming a classic in the Latin American social sciences literature on the prognosis of the "periphery's development" and "growth" vis a vis the "centre". The text, branded since its inception as the Latin American "manifesto" for development.

Therefore "development" is a theoretical construct after Second World War. Before the First World War, Eurocentric, or Anglo-Saxon economic and sociological discourse reigned supreme: it was unashamedly teleological when it made reference to those "backwards areas". Furthermore, H.W. Arndt shows that the notion of "economic development", in those areas was seen in terms of opening and "exploiting natural resources". Those notions cannot be made easily harmonious with "wellbeing of the population" and "growth per capita" generated in the 1930's and 1940's with the construction of the national incomes accounts and "Keynesian" macroeconomic models. As Robert L. Heilbroner, Joseph Love, and H.W. Arndt 
have insisted, before the Second World War little was written on the "backwards areas" that was not thought in terms of a "stage" that had been superseded by the "industrial" economies.

Although Prebisch was not ECLAC's Secretary General until 1949, his important role in its recognition and creation (a product of his work style and passion which he instilled at the ECLAC), can never be exaggerated. In terms of his ideas on economic development, speaking in theoretical terms, he can truly be considered a pioneer and progenitor of a long lasting tradition in this field in Latin America, if not in most "Third World" countries. Part of his legacy relates to his belief and struggle for the creation of an institution representing those countries that had come to specialize in the production of primary or raw materials in general, worldwide and/or particularly in Latin America, which would promote and monitor their development. His share of élan in the fulfilment of the ECLAC project could be seen once again during the 1960s, when he left the organization to become Secretary General of the UNCTAD and subsequently head The Latin American Institute of Social and Economic Planning (ILPES), a project and proposal of his own making in 1962 whilst still at ECLAC. During the 1940's and 1950's in the majority of Latin American countries, the universities created new economic and sociological departments driven by the political movements and governments purporting to sponsor growth and "development" processes. The rise and decline of the perspective to be described below can also be seen in transformations of the "economic" and sociology departments in the universities in the region between the 1950's and 1990's. The description of the development of the region and political milieu of the Latin American of post Second World War, requires that we trace some of the ideas, posing them as "ideal types", given the ample fertile tradition in Spanish and Portuguese of the discourses in question and certain personalities within the Latin American structuralism tradition (R. Prebisch, C. Furtado) and "dependency approach" (F. H. Cardoso, M. Marini).

\section{Latin American structuralism}

By the second half of the 1940s the pre-eminence of Keynes work on the possibility of resolving the "cyclical" nature of capitalism through some kind of planning or demand management cannot be put into doubt; his name and his ideas were synonymous with a "revolution" in economic science at academic institutions all over the world. The fruitful results of his ideas over time and space, and in practical terms, especially in Latin America during the early thirties, were soon to be recovered to argue that Eurocentric economic discourse has limitations, and that the Keynesian categories had to be transformed. This task was soon undertaken by R. Prebisch, J. F. Noyola, V. Urquidi, R. Boti, A. Pinto, O. Sunkel, D. Seers, C. Furtado, to name but a few.

On the other hand, "economic science" could not go further than reiterate its new-fangled categories when thinking of the periphery or the "backward countries". There was a brutal silence, and absence of a specific theoretical discourse in reference to countries that were plainly not "industrialized". The emergence of the notion of "underdeveloped economies", following the Second World War, which singled out late-comers to the growing industrialization process or raw material producer countries, was the product of a crucial theoretical and political battle fought by institutions such as ECLAC. The posing of a process of industrialization and transformations of the periphery (fiscal and land reform, modernization of its state apparatuses) became the centre piece of ECLAC thinking.

During the mid-1940's Prebisch himself was very reticent to adopt the so-called "Keynesian revolution" vocabulary and very critical of its work as well as much of economic science. The asymmetric mechanism of distribution of productivity gains or the "fruits of technical progress", between the centre and the periphery in Prebisch's argument has nothing to do with "imperialism" whatsoever. It just so happened 
that during "the upward phase" of the cycle, prices of raw materials of the periphery rose at a much faster pace than the correlative products of the centre, while in the down swing phase prices of raw materials declined much faster than industrial products and the new market "clearing" price of primary products find themselves requiring to sell a much larger quantity of products to buy a similar proportion of manufactured goods during the next cycle. Whether it was a question of differing demand-price "elasticity's" for their respective products and/or because the centre's better organized homogeneous labour organizations managed to defend its income level better than the periphery, a deterioration of the terms of exchange ensued, which in Prebisch eyes did not lead necessarily to categorize the overall mechanism as "unequal", for two reasons which for lack of space cannot be explained in full: (a) Since 1946 , Prebisch had been arguing that the notion of "equilibrium" was a mystical notion, and (b) therefore the price mechanism and money did not "represent" anything external to itself other than being a unit of account, thus his condemnation as "metaphysical" all those discussions about "value" in the early days of marginalism or classical economy as labour content ("use value" and "exchange value" and so on).

Prebisch argued that there was an intrinsic constitutive reason that explains the life existence of the cycle: Time is the culprit in question, and more specifically "time disparities", between the centre and the periphery. Differing time phases between the productive and circulatory circuits. Classical and neoclassical economics eluded this issue by introducing money as a "vicarious" entity to restore a balance between the real and financial levels of the economy. But for Prebisch there is a systematic asynchrony between the diverse productive cycles and the financial-money cycle (a time disparity), although "money" is reintroduced post factum in traditional accounts of the economy and history of thought. The bank rates managed by the Bank of England in the first "cyclical centre", would attract and/or expel gold during the differing periods of the cycle, leaving to the periphery the task of adjusting its overall internal and external accounts to this "untimely" movement. Its time disparities that cause the systematic wave-like motions of capitalism.

At the First Meeting of Technicians on Central Banking Problems of the American Continent, Prebisch stated: "I find myself disturbed by the thesis that free competition leads to general equilibrium and to the most adequate distribution of the resources and income within the community. I do not see any correspondence between these abstract propositions and the reality of the economic world" (1993:227). Capitalism was essentially unstable thus the importance of money and fiscal policies. As Prebisch observed: "I have found only but wave motions, a succession of ascendant and descendant wave motions. (...) The cycle (...), in the centre as much as in the periphery, is the characteristic form in which the economy grows -the capitalist economy has not had another form of growing than the cyclical form" (1993:226227).

We could also see how Prebisch appropriated some of Pareto's work. As Pareto explained: "In reality, equilibrium is never reached, since, as one approaches it, it alters continually because the technical and economic conditions of production modify themselves. The real state is, therefore, that of continued oscillation around a central equilibrium point, which itself moves" (McLure 2001:76).

It must be said, however, that Prebisch did not make explicit these theoretical considerations at ECLAC. He was adamant that his purpose there was to produce practical and well organized policies and technical advice to development projects: "We have presented at different sessions of the Commission a flow, at times abundant of documents in which the economic phenomena of Latin American countries are analysed, interpreted, ordered; studies that could be judged as eminently theoretical. Gentlemen, it's true that reality persuades us more so that practical action should have a theoretical base, be it in economic 
matters as in any other field of knowledge; but to conclude from this that the permanent organization of ECLAC is an instrument of theoretical analysis would be a serious, a very serious error because it would mean distancing oneself by the path traced by this Commission in successive meetings. The ECLAC organization is not a theoretical instrument, not a body of scientific investigation, but rather it is inspired by eminently practical purposes, objectives that have been defined and reached, perhaps, more clearly at the Conference in México (...) ECLAC as an organization of international action (...) can examine those forces that act deep in the womb of the economy of the Latin American countries (...) (and) find a solution to our immediate problems (...) determining the technical necessities of the countries (...) the necessities of investment of capital; studies of the techniques of investment programs (...) contribute to the formulation of policies of development; and (...) training economists in problems of development" (Prebisch 1952:24-25, my emphasis).

Prebisch reminder of ECLAC's mission and reprimand represents just one of a series of difficult episodes at the organization. Celso Furtado, since joining the organization, had been very busy taking Prebisch thesis on the universal fallacy of the economic orthodoxy. Side by side with his organizational tasks, having directed An introduction to the technique of programming (in 1953 and revised in 1955), he also published in 1954 his first book The Brazilian economy: a contribution to the analysis of its development dedicated to Prebisch. The role of the "multiplier" and the "accelerator" were crucial to many of the calculations that would be undertaken to postulate specific rates of growth. The recommendations towards a full employment policy admitted that the economy could not be seen as a self-regulatory entity. Fiscal policies and management of interest rates as well as budgetary deficits were part of a process aimed at maintaining a certain level of employment and income. What came to be known as demand-managed economies gave clear indications of the results that could be accomplished through the promotion of economic "growth", well above the expectations of "market forces", in spite of the downward undulations and "cyclical" nature of capitalism.

Prebisch's ideas, and later those of Furtado, opened up a vast uncharted theoretical landscape, which henceforth would be mapped by means of new categories which would incorporate planning as one of the methods to induce a programmed process of development. Since the thirties, Prebisch had been experimenting, with great difficulty and not much success, with various explanations to account for Argentina's topsy-turvy economic development, including those that took their starting point from conventional economic categories: the cyclical notions of capitalism and the "Gold Standard", were parameters that left much to be desired, and could only be fitted to Argentina's experience through an unquenchable violation of the facts.

By 1948, Prebisch had initiated a theoretical perspective that would culminate in a specific discourse in reference to the so called "primary goods producer" countries or the periphery of capitalism. In other words, he thought that what was needed to address the "periphery's" problems, could not be deduced from Keynesian and/or neoclassical models of development. It was therefore paramount to differentiate the raw material producing countries (the periphery) vis a vis the "centre" or industrialized nations. He was arguing against the plainly "false" claims of "universality" of the economic discourse hegemonic at that time, which in the last instance assumed that the countries of the periphery should undergo similar structural transformations during their development process as those that the industrialized countries had undergone in the past, adjusting themselves to world economic forces; a concept of history which L. Althusser, in a polite and paradoxical manner, has termed as "future anterior". 
Under this scheme of things, "backward economies" had to adapt themselves to an international trading system that blessed its relative abundance of factors of production. There arose a version of an international system of trade, which reinforced the hitherto international division of labour: the periphery had to specialize in the production of raw and primary products, and the centre concentrates on the production of manufactured products.

These countries were supposed to utilize those "factors of production" which were in relative abundance, and thus cheaper, to produce specific goods. Accordingly, there was a "comparative advantage" (no doubt in static terms) that favoured some countries to concentrate on the production of certain products that required diverse intensities of capital and/or labour. The surplus production would form part of the trade pattern that would maximize the overall growth and earnings of respective economies.

Today's literature has been evaluating the "robustness" of what has become known as the Prebisch-Singer thesis, although Prebisch had been showing statistically the "worsening terms of trade" or "worsening price relations" since the 1930's for Argentina. It seems that those countries that had actually followed the specialization path in its trade relations, and had accordingly adjusted their economies to the cyclical growth process of capitalism, found themselves, in the long run, in a worsening spiral situation. If, as he argued, the diffusion of the fruits of technological progress should have favoured the periphery, given its lower productive or technological capacity/intensity, so it should have manifested itself in lower price levels for manufactured goods imported. But the international price index revealed otherwise; this by itself did not prove, nor explained what came to be known as the Prebisch/Singer thesis of the "deterioration terms of trade" of the periphery vis a vis the industrialized centre. What was claimed was that after the continuum repetitive cycle, the periphery, besides not being able to hold on to its own "fruits of technological progress", also lost them through the downward pressure that was exerted on the prices of its goods.

The periphery's terms of trade deterioration vis a vis the industrial nations, was due to the existence of a systematic asymmetric "elasticity" price demand for their respective products. Given the power asymmetries in question, the centre managed to preserve their price and cost levels, even, and despite the downswing in the cyclical process. It is true, as Prebisch argued that the gains (prices) in primary products during the upswing rose at a much faster pace than their counterparts at the centre's, but is also historically correct, that during the downswing, they declined and lost much more than they had gained previously. The so called debate on the "strange persistence of the terms of trade", and the proofs of its "deterioration" or not, ever since its inception, despite many of its authors contentions, disregards that the main contention of Latin American structuralism was to question the idea that the "international division of labour" is a "natural" phenomenon; in other words the conundrum epitomizes one among other geographical divisions, which represents the presence of power asymmetries, within and between different countries, regions and periods, and therefore not an insurmountable iron law. The absence of a "worsening" tendency of the terms of trade was not an oversight of the perspective in question: quite the contrary, it helped to underline that contingent power asymmetries should and could be changed, explaining the importance of the political strategies for the structural transformations.

Another aspect which formed part of the explanation of the "worsening terms of trade", had to do with the differing import and export coefficients, between the trading entities; previous to the great crisis, the then hegemonic cyclical centre, the British Empire, had what can be called a relatively high import coefficient with respect to what was going to happen to the world economy once the USA took the hegemonic role during the interregnum of the peace before the Second World War. To preserve the 
hitherto level of export earnings the periphery had to increase the quantum of its exports, intensifying its productive capacity, which in turn increased its demand for imported goods (semi-manufactured and manufactured), constraining the diversification of its economy. Thus every cycle saw the imposition of a systematic tendency: the deterioration of the periphery's terms of trade with all the subsequent negative consequences. The search for an elusive "equilibrium" meant a lower rate of investment, higher levels of savings, and a reduced capacity to receive foreign credits and therefore overseas capital. This had to be resolved by attracting foreign capital through an internal deflationary process, all of which stalled the growth of the economy.

The growth of income in the centre was not reflected in an equally proportionate increase in the demand for products or goods from the periphery; on the contrary, a whole series of substitutes and "demand" schedules appeared for other, and more elaborated types of goods, which for the periphery meant a reduction in demand for its goods. The periphery's growth was therefore inhibited by internal and external disequilibrium's given its lower capacity for imports, which in turn explained its stop-go characteristics. Modern literature has resuscitated this aspect of the power asymmetries phenomenon as the Thirwall thesis of "balance of payments" constraints in a growing economy, converting it into a problem of priceincome demand elasticity's disparities between different economies. For Prebisch the problem was not "absolute export earnings" decline, but rather to what extent they generated internally the appearance of sectors whose "productivity" was higher than those concentrating on exports. And given the historically relatively low "import coefficient" of the United States economy, an "inward drive" development seemed the only practical option for the periphery.

Thus all manifestations of the periphery's erratic growth process throughout the first half of twentieth century, largely based on the external demand for its goods, pointed towards a policy that required a sponsored process of internal productive diversification, which in the last instance meant the industrialization and structural transformations of these peripheral countries. In Prebisch's proposal, a "programmed" process of industrialization would in turn allow for the absorption of underemployed labour or those displaced from less productive sectors; its employment in the secondary and tertiary sectors would secure a higher level of employment, which would in turn destroy the social forces which kept wages down that reinforced the life of old quasi feudalistic relations in agriculture, with low costs and extensive methods of land use for production of raw or primary products in many countries of the region. The industrialization process would substitute some imports, changing its composition, and creating a mechanism to hold on to some of the fruits of the technological progress. A more diversified economy presumes higher factor "prices", which in the long run could be the basis for the export of industrial manufactured goods.

Prebisch also sponsored a broader common market arrangement, with some important early fulfilments of the strategy in Central Latin America, similar to today's regional agreements in Latin America, which would facilitate the lowering of costs and the use of ample economies of scale for new industrial sectors. Initially, some industries would produce some goods at higher prices than those in international markets, but as the industrialization argument runs, in the long run those "Ricardian losses" (Prebisch's expression) were a positive element in the trade-off between having labour employed in industrial activities or importing cheaper products, which through the multiplier effects would generate incomes and demand internally. Besides creating a more "homogeneous" economic base, the substitution of imports with local production -industrialization-, would also enable a better control of the economy during cyclical downturns. In this sense, programming the rate of growth and industrialization was seen as a way to help "market forces", not stifle them, as most neoclassical or neo-liberal misinterpretations of Prebisch 
claimed. The same process of reforms to transform land possession meant the creation of smaller capitalized productive units generating economic forces away from the hegemonic conservative "haciendas" sector, economically and politically, giving life to "markets". Later on we will return to this aspect of Latin American structuralism, but it is worthwhile to underline that the dependency approach perceived from its inception these political features which obeyed great part of its criticisms.

Simultaneously, during the 1940s and 1950s, Brazil, under the sway of strong nationalist social forces, became everything that the so-called "ideology of developmentalism" represented. The political forces headed by Vargas and a large number of institutions like the Superior Institute of Brazilian Studies (ISEB) pushed the industrialization process into most of the plans they had a chance to come up with, culminating with Juscelino Kubitschek's ("Targets Plan") economic plans.

After the war, the National Bank of Economic Development (BNDE) was founded and soon made agreements with the ECLAC to work hand in hand in many development projects. The Joint American and Brazilian Commission, which was formed to enhance the industrialization process, had Furtado as its Director. Brazil became, in the first half of the fifties, a theoretical paradise for discussing and experimenting on the theme of "development". Most of the leading exponents, G. Myrdal, R. Nurkse, of a full-speed-ahead-towards-industrialization policy and critics, J. Viner and L. Robbins the structuralist's terror, visited the country during that time and discussed the topic.

Furtado was to establish a specific debate with Nurkse on the issue of the size or otherwise of the market as a limit to the capitalization and development process. It's important then that we should extend ourselves a little on Furtado. From his taking up a post at ECLAC in 1949, Furtado had been working on a whole series of projects that kept him in close contact with Brazil and the growth of the Latin American economies. Two aspects dominated and predetermined Furtado's theoretical and practical interests during the early 1950's. On the one hand, his examination of the evolution and transformation of the Brazilian "economy" from its inception as a colonial entity, with particular attention given to the postslavery period; and on the other, accounting for and interpreting the rise and history of economic ideas as the royal road to knowledge of the periphery and the process of development. He clearly wanted to continue the critique of economic theory to its radical roots, which Prebisch had initiated, elaborating a more specific theoretical vocabulary.

Furtado's first published book The Brazilian economy had two quite distinct characteristics. On the one hand, it was comprised of a historical description of Brazil's "economy" from its colonization up till the decade of the 1950, and on the other, we had one of the first documented histories of economic thought. It focused on the problems of "backward" economies, demonstrating that orthodox economic categories references towards "underdeveloped economies", had only the function of signalling "differences", with respect of "developed" economies, and worthless to think the specificities of an "underdeveloped economy".

The concept of an underdeveloped economy as a distinct entity with its own logic and structure was already being processed conceptually, culminating in fully fledged discourse during the years of 19581962 , displacing the teleological and evolutionary notions implicit and explicit in conventional economic discourse, Keynesian included. To start with, the notion of an "underdeveloped economy" starts dislodging the hitherto category of a "colonial economy" dominant in much of the text. By 1958, Furtado was convinced, although not yet completely theoretically armed, that the Latin American economies were specific historical entities that could not be explained with the traditional vocabulary of mainstream 
economics. Paradoxically, Prebisch was very critical of Furtado's ideas, which in turn made Furtado ponder leaving ECLAC. We could even speculate that to keep him away from the centre of attention he was regularly invited to participate in various economic reports and commissions, starting in the Brazilian and United States Commission and later, through his sudden trips to prepare reports in Venezuela and Mexico.

After 1954, Furtado's cyclical notions of capitalism started disappearing. Theoretically, Furtado started thinking more in "structural" terms, "obstacles" or "structural transformations"; concepts that could think productive agents embedded in specific social relations and historical contexts, displacing the "rational" maximizing entities espoused in the official economic discourse. It followed that a theoretical reconstruction was in order, and accordingly, "underdevelopment" could not and should not be thought of as a historical phase to be overcome, but rather as the outcome of the hegemony of a specific set of asymmetric social relations whose articulation produced many of the disparities and "heterogeneous" phenomena once thought of in "cyclical" terms. Thus, a specific body of conceptual tools had to be constructed and that was precisely what occupied Furtado between 1958 and 1962.

As mentioned before, the evolution of Anglo-Saxon economic thought, inapplicable for the analysis of the periphery's development, and even resembling his own research, appeared in the results of a conference held in 1951 at Chicago University, which Furtado read in the following manner: "The theory of economic development does not fit, in general terms, within the categories of economic analysis. This point of view is quite generally accepted today, and it suffices to quote the seminar on development organized by the University of Chicago in 1951, in which sociologists, anthropologists and historians where gathered alongside economists" (Furtado 1954:193).

The process and evolution of Latin American structuralism did not appear in "one fell swoop", as it were. In fact, it was painfully achieved during a period when he was fighting crucial political battles to transform, first the Northeast, in Brazil, as its first Superintendent, and secondly, as the Minister for Planning. By 1957 Furtado had left ECLAC. After spending a short period at Cambridge University, he returned to Brazil where he took up the post of Director for the Northeast section at the National Bank of Economic Development (BNDE). He would later head projects to develop the Northeast. It was during this period that he published The economic formation of Brazil, a text that incorporated most of the historical sections of the previously mentioned book The Brazilian economy.... But this latter version came with all the appropriate reformulations so as to give it a distinctly "structural" flavour.

Between the appearance of this book and the period of 1964 when he was exiled and forced to leave Brazil by the military regime, Furtado fought on many battlefields. He produced books and articles with distinct political and/or academic texts, and some of a controversial nature. The latter can be exemplified by the text entitled The Brazilian pre-revolution in 1962, a recompilation of a series of articles with the one used for its title being the most politically explosive; a good example of the former can be seen in Development and Underdevelopment of 1961, also a reordering of some of the material found in The Brazilian Economy..., appropriately reformulated, and also containing new material.

In his first stop of exile in Chile, at the ILPES in ECLAC, Furtado offered a series of conferences. On June 3rd 1964 he was to present the origins of his theoretical recent position that was to last till around 1972. He represented an economic tendency for Brazil and Latin America which showed a declining process of growth and industrialization. Here we can observe the notion of the "structural obstacles" and "stagnationist" thesis for the economy on the whole. The conference initiates the argument of what was to become subsequently the book Underdevelopment and stagnation in Latin America. That text presents 
all the genealogical conceptual elements that were to appear in Cardoso and Faletto's classical text Dependency and development in Latin America. In turn, Cardoso's book circulated in manuscript form since its inception in 1967, two years previous to its publication, as an internal document of ILPES - ECLAC. The Furtado lectures were attended by various of the names that are later to conform the "dependency approach": Fernando H. Cardoso, R. Cibotti, N. Gonzalez, José M. Echavarría, O. Sunkel, Pedro Vuscovic and F. Weffort, amongst others.

\section{The dependency approach}

The vision and perspective of the "dependency approach" cannot be reduced to the issue as to when was the category first mentioned. For example, Kahl remarks that Cardoso first uses the term "dependency" in 1965. In Latin America there is an extensive discussion as to whether it's an "autonomous theory" or the theoretical product of addressing a critique to the economism and "pessimism" of the future of economic development of the region, of which Furtado "stagnationist" thesis was an exemplar for that period of his life.

Also, the Economic Bulletin of ECLAC in 1964 prognosis of certain difficulties on the future process of "industrialization", could and were turned into a "pessimist" perspective on the future prospects of the development process as a whole, underlining relatively higher costs in comparative terms and a difficult process ahead when the capital-intensive sectors were considered. The first "stages" in the industrialization transformation/expansion, of consumer's goods, substituting imports by local elaboration, apparently seems to have reached a cull de sac. Also it gave rise to abundant uncertainties on the capacity to pay for imports and/or rates of "exploitation" required to pay for them as "dependentists" had pointed out; these aspects of the problematic nature of a "development" process articulated to the world market, overwhelmed the discussions in the dependency approach and Latin American Structuralism alike.

In the "stagnationist" book, Furtado presented explicitly the first Latin American "structuralist" model. Its content presented all of the conceptual characteristics that would later appear in the writings of those that were to adopt or follow the above-mentioned denomination. It clearly highlighted the social-political forces that are the basis of "internal" or "external" dislocations of an economy and that tend to reproduce the conditions that constituted the "underdevelopment" condition, or so Furtado argued then, notwithstanding the industrial progression in some of the economies in question.

The text was the culmination of what was to be Furtado's specific "structuralism". Although this book exhibited a very pessimistic view of Latin American economies' future rate of growth and industrialization, we now know that what he was actually criticizing and disapproving of, and confusing with an inherent "stagnation" tendency, the systematic and intrinsic mechanism of exclusion by capitalism to marginalize the majority of the population from the fruits of their technical progress. For the first time, Furtado's overwhelming nationalistic tone questioned the role of foreign capital in the conformation of the debt pattern and its productive role in Latin America. This was a theme that would never again become peripheral to his intellectual and political activities.

ECLAC always viewed foreign capital as merely a transitional phenomenon in Latin American economies, required only to undertake the initial process of capitalization, given the low level of "savings". Furtado felt betrayed by the United States' promises and policies for the Alliance of Progress during his time at the 
forefront of development of the Northeast, which in part also explains his pessimistic tone after the Brazilian military coup.

Furtado started with an examination of the "external" factors that he believed crippled Latin American economies (U.S. policy), and then moved on to describe the "internal" limits of the industrialization process within Latin America. In this aspect, he argued that once the easy period of the industrialization process was over (consumption goods), substituting certain imports through local production, the next phase (capital goods) posed inherent limitations to incorporate a broader number of the population within the growth of the economy. Furtado considered that the substitution of capital goods imports with local production required an overly intensive capital function, which in turn stimulated higher level of imports. The other side of the equation showed that it absorbed a relatively low level of the labour force from the "backward" sectors of the economy. Aside from the fact that the higher capital intensive function required a much higher level of savings, which the upper classes did not and would not supply, given their traditional historical behaviour, the market size for its goods hindered the benefits of fully fledged economies of scale. As a result, everything seemed to work towards lowering the productivity level of the economy as a whole -not just the capital-intensive sectors- thus ensuring the stagnation process of the Latin American economies.

Cardoso and Faletto questioned the inherent stagnation tendency arguing that development is "dependent-associated" on the alliances and powers of the social classes involved, but capitalism will certainly continue to advance in the region, therefore the actual historical period did not necessarily mean the end of the continuation of the process and the transformation of the societies. The book by Cardoso and Faletto devoted plenty of space to describe the differing historical situations in Latin America, within and between countries and economies, to present the case for the possibility of a "dependent-associated development", showing therefore the fertile use of some of the elements of the Latin American structuralism perspective. The theoretical consummation of this flank of the "dependency approach" meant displacing the classical Marxist notions of classes to explain the political agents and process in question, which is a theoretical aspect that would be contested by Mauro Marini in the majority of his work and debates with the Cardoso and others. Furthermore, Cardoso's perspective also interrogates and disputes the Gunder Frank's thesis of the "development of underdevelopment" as can be seen by Theotonio Dos Santos own definition of a situation of dependence: "dependency is a conditioning situation in which the economies of one group of countries are conditioned by the development and expansion of others. A relationships of interdependence between two or more economies or between such economies and the world trading system becomes a dependent relationship when some countries can expand through self-impulsion while others, being in a dependent position, can only expand as a reflection of the expansion of the dominant countries, which may have positive or negative effects on their immediate development. In either case, the basic situation of dependence causes these countries to be both backward and exploited" (Dos Santos 1978:305).

But this synthesis represents the theoretical transformation undergone by the dependency approach dominated by its "Marxist" vocabulary. Marini's work depicts clearly this aspect vis a vis, those who followed Gunder Frank's vocabulary, and the Cardoso and Faletto camp. The political and intellectual period, marked by the Cuban revolution, especially once it was declared "socialist" in 1961, was under the presumed alternative that in the last instance countries in the periphery had to leave the "capitalist" and "imperialist" trading system if they were to develop their economies. Retrospectively, in reference to the 1964 military takeover, Marini signalled that the "conflict would soon explode [...] between differing 
processes of surplus-value extraction -relative and absolute- between those highly concentrated capital sectors [and the small capital] technologically backward ones" (Marini 1974:150).

Cardoso and Faletto's interpretation of the period in political terms is similar although the tone and vocabulary differ radically: "Therefore, development, from that moment on is undertaken intensifying social exclusion and not just of the masses, but also of the economically significant social strata of the previous stage, whose principal alternative was to achieve some form of subsidiary vinculation to the modern monopolist sector and the political domination it installed" (Cardoso and Faletto 1975:151).

Marini's thesis brought to light a specific reading of Marx's theory of value to explain the commercial ties with the world market and the peculiarity of the labour process and the "extraction"/exploitation mechanism dominant in the region. The reading in question forms the basis of his attempt to save an explanation for the use of the category of "underdevelopment" for the periphery of the capitalist world economy. On the other hand, in its first versions, the theme and vocabulary of Gunder Frank on the mechanism of "appropriation of the surplus" generated by the "satellites" by the "metropolis" seems to be the product of today's classic work of Paul Baran: Monopoly capital: an essay on the American economic and social order and The political economy of growth. The notion of "surplus" was not given much explanation or elaboration on the part of Gunder Frank, simply assumed as what could be siphoned off from the "satellites", in distinct historical periods by the "metropolis" given the asymmetries of power and the imperialist strategy. The asymmetric contradiction: metropolis/satellite could also be an internal occurrence and differentiation within the same region or country. It was this mechanism that explained the oscillating manner by which a specific expansion or development of a certain region "underdeveloped" its "trading" or commercial counterparts.

There is sufficient literature in the Anglo-Saxon world that discussed, since its inception, the Gunder Frank's thesis, empirically and conceptually. In the mid-sixties, part of those arguments seem to echo in Latin America, when the "Latin America's structuralist" stagnationist thesis was discussed. Among the proponents of the dependency approach a profound theoretical discussion arose as to the pertinence of the "heterogeneity" notion developed by Latin America structuralists and the power asymmetries in the countries and regions. The regional articulation to the world market became the centre of the analysis via the reconstruction of Marx's theory of value, therefore establishing a conceptual mechanism that could explain different and distinctive processes of extraction/appropriation of the surplus among and between diverse social formations, some capitalists or proto-capitalist's and so-called "pre-capitalist" ones. Simultaneously, this would provide the conceptual vocabulary to explain the internal difficulties of the periphery to continue its development path notwithstanding the "underdevelopment" condition.

When talking on the "central economies" Marini argued that the: "general rule has been the intensification of the exploitation and therefore, accumulation through the real cheapening of the labour force, achieved principally through the reduction of the value of the goods that are required for its subsistence (...) the constant devaluing of the labour force has constituted the decisive element in the production and capitalist accumulation of the central economies (...) its not rigorously the case in the capitalist economies of the periphery (...) these economies have undertaken its process of accumulation fundamentally based in the production of absolute surplus value (...) In other words, the increase of the surplus labour time tends to be realized without altering in fact the necessary labour, but rather by not reconstituting the value to the worker which he creates during this setting; therefore what would seem relative surplus value, frequently is, an anomalous case of absolute surplus value. (...) Lets make clear the point: the augmentation of the surplus time-work always signifies a greater exploitation of the labour force" (Marini 
1974: 114-115, my emphasis). Marini also says: "Still, it's possible to identify a mode of increasing surplus value, by which the reduction of the wage is not in correspondence with a real decrease of the necessary labour time. This case tends to be exceptional in the advanced countries, but embraces a generalized characteristic in backward countries, like Brazil, where it configures the super-exploitation of labour. Exclusively for the purpose of simplification, in the text, we use the expression of absolute surplus value also to denote this last modality" (Marini 1974:148).

Kay's reading of Marini seems to uphold this interpretation "over exploitation is not identical to absolute surplus-value. Sotelo has recently underlined once again the political importance of the Marini/CardosoSerra debate at the end of 1970: "In contrast to Marini, Cardoso and Serra conceived of labour super exploitation as a conjectural phenomenon and not as a process endogenous to capital accumulation in dependent economies. In the same manner as Ricardo (whose work Marx criticised thoroughly), moreover, they calculated the increase in the rate of profit in a way that conflated the rate of surplus value with the rate of profit" (Sotelo 2014:544). In Marini's interpretation, the Brazilian "military dictatorship" could be seen as the "inevitable consequence of the Brazilian capitalist development" in its "desperate attempt to open up new perspectives for its development" (Marini 1974:97), with its repressive and exploitative labour laws.

Another way to read Marini's concepts of surplus-value and super-exploitation is not to question its "consistency" with respect of a supposedly Marxist tradition, as if the notion of the labour theory of value is something unproblematic. It's precisely this line of thought that the Latin American structuralist perspective developed, problematizing Marxist and neoclassical notions of value and price alike. It argued that the idea of asymmetries of power and exploitation between and within units of production and the labour force did not require a general conception of value to explain certain specific inequalities and indefensible distributional patterns, and in that sense Marini's argument can be defended as a consistent manner to examine the labour process and power asymmetries in certain sectors and regions of the world. In other words, this means that it's the whole classical political economy tradition that had to be overhauled and questioned. A reading of the period and its authors in a structuralist fashion, converts the notion of power as its centre of analyses and examines the differing mechanism by which social relations delineate and determine the possession in separation of certain conditions of existence of the productive units, mechanism by which a "market" and a commodity circulation emerges. This mechanism in turn explains how the exchange process determines the distributional context between different agents. In this sense, there is no market in general and no necessary articulation of certain social relations to specific forces of production. These are transitional and contingent upon certain historical cultural traditions and specific processes. The heterogeneous nature of much of the "economy", "developed" and "underdeveloped" alike, proposed the idea that there is a unique way to organize the productive process and achieve efficiency and equality. That is one of the central ideas that Latin American structuralism developed theoretically through its historical analyses. Structuralism has always sustained that its perspective theoretically supersedes (in Hegelian fashion) the "classical" and post and Keynesian school of thought. It's worthwhile then to observe some of its vocabulary through the work of Furtado.

By the mid-sixties Furtado said: "Economic structuralism (a school of thought that arose in the first half of the 1960s amongst Latin American economists) has as its principal objective to take into consideration the importance of the 'non-economic parameters' contained in macroeconomic models. Given that the behaviour of these economic variables depends mostly on these parameters they have to be the object of meticulous study" (1967: 81). Thus the emergence of economic plans, for example, implied "land reforms" (Furtado 1969, chapter XXIII), so that the "structural picture" could be modified and the social agents in 
question be freed to take up better remunerated positions within the social division of labour, which in turn would presumably favour a more equal distribution of incomes and resources. It supposed an advancement in the "knowledge of real structures", so that on many occasions it demanded the super session of "conventional economic analysis" (1969:297). Furtado insisted that his perspective had no direct relationship with the French structuralist school, "whose main orientation was to give importance to the synchronic axis of social analysis and establish the 'syntaxes' of the disparities in social organizations" (Furtado 1967:80).

Traditional conventional economics cannot take account for, nor explain the existence of "structural obstacles" or "heterogeneous agents". Thus the perspective rejects the notion of the existence of "homogeneous factors with the same technological time horizon" (Furtado 1969:102). The problems of "underdevelopment" needed to incorporate ideas of a non-unified labour market and the simultaneity of diverse productive functions, depending on the "surface of the economic structure in which the productive agent is inserted" (1969:102). The theoretical emphasis therefore tries to destroy systematically the traditional appearance of these problems within separate compartments, be they "economics" or "history". In a sense, Furtado rebuilt into a theoretical concept a notion that for Perroux appeared to be an obstacle or ephemeral phenomena that needed to be reformed: "Structural inflation has adulterated the very notions of our science; that is to say, it has warped or broken the modern instruments which are necessary not only for the diagnosis, but also for the treatment or operations that are indispensable for its cure" (Perroux 1957:263).

Furtado's theoretical deductions had already appeared in his description of the evolution of the development of Brazil during the early 1950's in which he distinguished between "dynamic" and "static" notions of inflation, a consequence of power asymmetries between agents and sectors, which later with the work of Noyola in 1956 were to be coined as the "structuralist" conception of inflation, underlining power asymmetries between different agents in the economy.

In this sense the 1954 book The Brazilian economy shows the initial steps of a theoretical transformation that can be found in Perroux's idea that specific and distinct economic units have differing "arenas", necessarily confronting each other. The so-called "equilibrium" or "relative peace" is the consequence of the hegemony of a specific productive unit o sector, which manages to establish a hegemonic role over a specific economic space and thus over other economic sectors. In other words, it's a question of the differing power asymmetries.

Retrospectively, developmentalist's and their critics notwithstanding, have to reckon with a post second world period, that before the "lost decade" in 1980 show rates of "growth" that have not been attained in recent decades. The much-predicted gloomy perspective for growth cannot be sustained since then. But the real absentee, during this period, are the structural reforms required to promote the "development" of the region, which can be said are the main dark aspects of the history during the epoch. The historical transformations: land and fiscal reforms were never in the political agenda, distributional aspects that would have provided the much need "demand" to defeat the so-called limitations of the "market".

Ever since the mid-sixties, structuralism policies on development have been evaluated in terms of its policy ideas towards the industrial sector, and yet that aspect forms part of much wider perspective of the role of the state in transforming the social and political horizon. The differentiation and apparent conflict between an "easy" phase of the import substitution "industrialization" devoted to the elaboration of the consumer or non-durable goods vis a vis the "difficult" stage which entailed the substitution of the 
"machinery" or capital sectors forgets that the issue was related a change in the "composition" of the goods imported: "the substitution process does not propose the diminution of the global quantum of the importation; the diminution, when it is achieved, comes imposed by the restrictions of the external sector and not by design. From these restrictions (absolute or relative) arises the necessity of producing internally some of the goods that before were exported" (Tavares 1964:5).

The periphery, tied to the limitations of its inherent external disequilibrium, given the tendency of the deterioration of the terms of trade and incomes, had to concentrate in developing certain sectors and geographical areas that could be sustained by a series of closely articulated policies, what later Hirschman would coin in terms of "backward and forward linkages" and the positive feedback all along the productive and sectorial chain. These aspects also tend to cloud an issue which is generally appraised in terms of the respective levels that can be deduced from capital-output and / or capital/labour ratios that present the heterogeneous horizon of those economies. And yet the structuralist perspective emphasized that "productivity" and investment had to be examined in the context of the power asymmetries of the units of production and regions involved, that required specific analysis in every case, by which it practically sidestepped the so called Cambridge capital controversies and "re-switching" of the sixties in the Anglo Saxon universities. The whole notion of development, implied a distinct version of thinking the "increase" of "productivity" levels which meant organizing the labour process in a different manner, as well as promoting changes in land tenure or "structural reforms" in general: the dynamic view implied that even if some nations produced at a higher cost some of its products instead of importing them, it would generate in turn new units of production and other necessities, changing the patterns of production and the "demand" in question. This way of posing the problems in ECLAC, demonstrates once again that they had no need of mainstream economics, nor proto-keynesian visions: prices and incomes were a contingent product of the asymmetries of power between and within certain sectors and regions. Structuralist's assumed the un-decidable dilemma trade-off between a relatively higher level of incorporation of the population towards the more productive of modern zones, or specific sectorial higher wages; it was a dilemma that had no easy answer, whether in the "paretian optimum" or "second best choice" of the capital intensity required, it simply could not be deduced in advance.

This vision for amplifying the radius and scope of modern "exchange" and commodity relations was to be criticized by Marxists theorists and the "dependency approach" alike. Simultaneously neoclassical criticisms during those years highlighted the investment strategies but for different reasons. The historical confrontation between, on the one hand, the "dependentistas" that maintained that structuralist's aspired to develop "capitalism" aiding a "comprador bourgeoisie" (a backward and corrupted capitalist class) with profound state interventions and on the other hand, neoliberal ideas underlining high level of protection and certain costly experiments and "state interventions" proclivities blocking the efficiency of the market through the "crowding out" effect of private capital investment, destroyed traditional policies and views on the role of the "market", transforming Latin American governments strategies. It was argued that the states' intervention, turned the whole process of investment and growth into a vicious negative circle, which lead to high levels of external debts.

By the end of the 1970's it was clear that "development" was not synonymous with "growth", implying among other things a series of reforms or structural transformations, reducing income inequalities between sectors, differences between various areas and regions, and could not be conceived independently of recovering and institutionalizing some form of a "democratic" regime. Thus the 1980 lost decade of growth in Latin America, withstood all the political struggles and various transitional processes 
which had to undergo the region to reach a form government based on a more open and competitive "democratic" process.

\section{Under the sweltering heat of the "Washington consensus"}

In the eighties, with an increasing external debt the periphery would show declining rates of growth and development. The international environment had changed drastically after the U.S. left the dollar free of its gold counterpart turning to relatively flexible exchange rates; in turn the higher petrol prices during those years created a massive liquidity that was to be "lent" at very low interest rates to any country willing to undertake the borrowing. An inflationary process surged that was to leave the periphery in a very weak situation to negotiate its external debts. The Brady plans to exchange bonds for external debt did not really solved the insurmountable payments with the level of interest rates then in process, which with the declining rates of growth of the industrial centre's generated a reduced level of imports from the periphery. That explains the negative rates of growth during the so-called "lost decade" of the 1980's although it can be taken to mean until the end of the 1990's in some countries.

The decline of state support for capital investment/construction can certainly explain the lower rates of growth and development in the periphery since the inception of the "Washington consensus" drive and the appearance of the so called "good economics" and the "Chicago boys" in our intellectual horizons; foreign direct capital did not occupy the vacuum left by the public and states' subsidies to local industry; the childish argument about the "crowding effect" by state interventions and subsidies took many decades before it was questioned, given the disastrous consequences for local industrial sectors and the economy in general. The process stimulating research and development in local industries has become one of the main aspects in which the State in the periphery is beginning to concentrate. The so-called market forces have not been forthcoming with its benevolent fruits as the globalization and "Washington consensus" initially promise. The great part of the investment and research is generally undertaken and "placed" strategically in "developed" economies, leaving for the periphery other less important tasks of the productive process in the best of cases when the direct foreign investment is undertaken by the big corporations.

The surplus of foreign currency to pay for the debt and interest of the current account, were given an important back up with the foreign exchange sent home by the great migration drive towards the industrial countries, given the absence of local alternatives: the periphery was converted into a vast camp of labour export sanctuary for certain economic sectors in the "centre countries". In contrast to capital flight and unregulated freedom by the "globalization" drive, the migratory forces were under the constant persecution and racist invectives of the local centre states, that was to be intensified once a downward growth tendency was perceived, lessening their capacity to increment the "price" of its labour.

Invariably in ECLAC a discussion arose as to the mode of sustaining and generating higher "productivity rates" and the industrialization process. It included a much-reconsidered reflection on the "openness" or other wise of the recent decades of the "industrialization" drive, which as mentioned before was not just a "neoliberal" criticism. The trends and direction of the generation of endogenous local technological rationalities was the starting point with the work of Fernando Fajnzylberg La industrialización trunca de América Latina, underlining the importance of developing an "endogenous nucleus" and "creative environment" with the corresponding social and political alliances to attract some form of foreign capital to intensify the accumulation drive, which really meant concentrating on sectors with high capital density, in tandem with a much more "open" and "free" environment heretofore in the region. Although the 
discussions linger on whether the "structure" of the final demand and incorporation of the labour force could be better intensified if industrial innovation strategies concentrate on the medium or smaller units of production, the work of Sunkel in the early 1990's (Development from within: toward a neostructuralist approach for Latin America) offered an interesting alternative theoretical twist. The work is presented as a supersession of Prebisch's and ECLAC's postures on its vision of the articulation of the periphery to the world markets and the corresponding industrialization process involved.

By then the region had to attune itself to what was called the "Washington Consensus" if it was going to receive some foreign lending or respite on the drain of its capital towards the industrial centre. The "reforms" imposed, implied it had to open up its economies lowering all rates of levies on imports, sell and privatize most of its public utilities sectors, and generate a surplus in foreign exchange, which meant advocating an export drive that in the short run could only be undertaken by the primary sector which generated the commodity boom export, which in the last instance became the centre piece of a strategy that reinstated in the long run all the uncertainties of the sustainability of the transformation in economies in question. The opening up of the economies of the region to the world market with the promise to receive foreign investment soon showed a declining tendency, after an early surge by big international corporations to buy the heretofore state public utilities ("un-manageable", "deficit" and "unproductive" as the tedious neoliberal jargon sung), followed by the cyclical arrival of foreign capital searching for higher bond rates earnings in the periphery. The hegemonic neoliberal regime came hand in hand with the imposition of the "Washington Consensus" and the myth of the globalization process.

Most of the adjustments and reforms consequent on the opening up of vast economic sectors to the international competition had also to do with the absence of macroeconomic "equilibriums" that were thought to be generated by the State's over expenditure, requiring important fiscal reforms that had also been a basic postulate of the structuralist modernizing strategy. In certain arguments it was a question of the distance o "non-convergence" between Latin America growth patterns, specially of its industrial sectors vis a vis the benchmarks or model of the industrial centre growth rates; others argued that transmission of knowledge and research alternatives had to be examined given that differing productivity rates could not be explained solely on factor productivity in question.

Sunkel was recuperating the structuralist vocabulary with the prefix "neo-structuralism", emphasizing and questioning the critique by neoliberal ideas that its strategies were inefficient because it opposed an open market and the freedom to interact and compete among different countries. If Prebisch's classic formula stated that growth post Second World War should take an "inward" direction for the periphery after a century of an "outward" drive, Sunkel generated an interesting twist to the issue. He argued that Prebisch's dictum of an "inward looking development" did not put sufficient weight on the particularities of accumulation, emphasizing the impulses that were generated by the expansion of the home market, and replacement of local production of those goods previously imported.

This last formulation leads to a strategy, which rests in the amplification of the internal consumption and the local reproduction of the consuming patterns, industrial production and technology of the centre, via the import substitution industrialization, fundamentally oriented by a narrow and skewed internal demand, configured by an internal unequal distribution of income. "The industrial strategy from within has very different implications (...) in the words of Fajnzylber, of an 'internal creative effort to configure a productive structure that is functional to the needs and potential national specificities' (...) internal creativity requires (...) a greater and stretcher participation and interrelation between different agents and incentives: big industrial plants linked to medium and small enterprises, scientific and technological 
infrastructure (...) Once the communication, interaction and fluidity of these actors, instances and levels of decision get consolidated as a national practice, it would have conformed integrally what is known as the 'dynamic technological endogenous nucleus' (Sunkel 1991:64).

Therefore, Sunkel's inward-looking development to development from within exhibit a search for a political and theoretical option to counter the so-called "globalization" and "Washington Consensus" policies. It seems to displace the question of the home market's limitations to absorb technological progress, culminating in the idea of generating an endogenous technology change emphasizing reforms and structural transformations now viewed in terms of the new forms of articulating the local productive units and the potentially conceivable associations with the world market corporations. First of all, the "structuralist perspective" and its policies were never the evil green monster anti-market or state-centered that neoliberalism narrative claimed; the post-Second War economic environment of the period imposed on some countries exchange control and State subsidies for industrial and other concerns, which were not very different to what had occurred during the evolution and growth of the industrial centre and inter war years. On the other hand, the social and infrastructure development conform to the patterns observed in the industrial centre's own evolution, as Chang reminds the academia in the Anglo-Saxon world.

In that context, Fajnzylberg proposed concentrating on developing the uppermost technological phases of industry, which generated an important debate with those whom argued for the support of the small and medium size units of production, given its higher rate of labour incorporation to the productive circuit, had a more positive effect on the economy as a whole and to the productivity level generated by each unit of capital or labour during the growth process. "Development from within" recovered some of the various alternatives to think and propose new ways to incorporate and defend for the periphery the fruits of its own technological progress, transforming the once apparently closed circuits between local capital and their foreign counterparts, into a more hospitable and competitive environment were the "State" would use other types of leverage to sponsor the industrialization and transformation of the periphery. What neoliberalism policies forgot in its "State-centered" invective in the region were the authoritarian and undemocratic regimes that existed during the 1970's and 1980's, which created many of the obstacles to the "developmental process" required for a higher "growth" drive to be undertaken. Neoliberalism's policies were complicit with the Pinochet's of the region that protected and sponsored so-called "individual enterprise" at whatever cost in terms of civil liberties.

Simultaneously by the end of the 1970's in Latin America, perceptions on the undemocratic regimes started to differentiate between "styles" or "approaches" of development, as well as O'Donnell's notion of "State bureaucratic-authoritarianism". They initiated challenging the then quite dominant conceptual horizon of the left in Latin American of the function of the State as simply an apparatus representative of the bourgeoisie "interests". Under the dictates of the period "Washington Consensus" we find a peculiar historical phenomenon occurrence in the Latin American region, especially if gauged by its intensity: the much vaunted process of inclusion and development, represents a period were the region intensifies the political and economic asymmetries, sponsoring the expulsion and exportation of labour: the much needed surplus of foreign exchange to pay for the region's external debt had been resolved through the mechanism of the "exportation of labour force" to the centre countries.

The recent social and political struggles in the region to confront the persistence of the neoliberal strategies, have generated a few political regimes which contest some of its main tenets: Venezuela, Brazil, Argentina, Bolivia and Ecuador; at least rhetorically if not in real terms, new policies have been developed to intensify certain rates of growth and incorporate the inclusion of the local populations in its 
development objectives. But we must evaluate these alternatives in the context of what has happened with the rise of world wind of neoliberalism and its consequences. The inequality in the region has not changed practically in the last 20 twenty years, sectorial and geographically, debates hinge on its amplitude.

Weak rates of growth globally again seem to be a basic limitation but also the structural reforms in the region have been delinking the productive processes internally by sale to foreign enterprises of certain productive units, which sponsored "commodities boom" primary exports displacing backward and forward linkages, by prioritizing the agricultural -export boom- without its "industrial" partner side. Also the land tenure and family agriculture have not received the subsidies or collateral for its sustainability; in some countries, agriculture has had to withstand the most retrograde of policies attempting to appropriate and concentrate the land in fewer units; its forms of possession in separation of some of its conditions of existence do not present any "modernizing" tone in any sense. On its external account, the region presents a much more stable and consistent behaviour, having tackled with success the 2008 financial meltdown in the U.S.

ECLAC much professed "hour of equality" corroborates much of the prognoses of a weak growth rate and yet relatively stable macroeconomic parameters. Reforms are needed to enhance the development in the region. But the elements which new policies should incorporate have to do with transforming the actual forms of possession in separation of the units of production, looking for alternatives in community projects and other forms of state and cooperatives participation. Macro demand management policies are not enough to change the actual logic of neoliberal "deregulations" which brought about a surge of economic, and much more dangerous, social polarization forces, marginalizing extensive sectors of the population, which had previously slowly been incorporated to the life of the nations.

\section{Concluding remarks}

The long trajectory of Latin American theoretical discussions presented, have not concluded, I tried to showed a certain peculiarity, emphasizing its distinctness with respect of Anglo-Saxon discourse, and since there are no privileged or sacred perspectives, construction of theoretical bridges can be undertaken.

Recently, under the authorship of Pérez "neostructuralism" and "heterodox" economics are placed as discussants of each other with the question as to what can be learned by their articulation. Whatever the resulting synthesis which we might reconstruct, Latin America "structuralism" finds itself placed in the difficult situation of having to choose between a discourse that understands the "economy" as simply portraying diverse and contrasting "elasticities" or as an antagonistic power asymmetric space between agents. Much (time) was lost by Prebisch himself, who did not close the dilemma until his last book Capitalismo periférico: crisis y transformación, underlining the heterogeneous nature of the agents in question, and the power asymmetry, which engendered them.

But there is still some hope: Anglo Saxon post keynesianism has offered something in that direction: "Contrary to neoclassical theory, and contrary in fact to what many Marxist and classical economists claim, there is no necessary inverse relationship between real wages and profits rates" (Lavoie 2009:122), a basic tenet of the deterioration terms of trade which surrounds the work of Prebisch, which equally can be bolstered by the "explorations" on "disequilibrium", as well as the reappearance of the "heterogeneous agents". 
But the political reforms required in the region have to reconstruct a much disarticulated "playing" field, which means that we must transform the way by which agents, regions and countries "possess in separation" the conditions of their livelihood; it's not just the question of resuscitating the "State", it also has to do with finding ways of incorporating the local populations in their own reconstruction: which brings us back full circle to the initial question of what we mean by "development".

\section{Bibliography}

Caravaca, J. 2011. ¿Liberalismo o intervencionismo? debates sobre el rol del estado en la economía argentina. 1870-1935. Buenos Aires: Editorial Sudamericana.

Cardoso, F.H. y Faletto, E. 1975. Dependencia y desarrollo en América Latina. México: Siglo XXI.

Connell, R. 2007. Southern theory: the global dynamics of knowledge in social science. Cambridge: Polity Press.

Dos Santos, T. 1978. Imperialismo y dependencia. México: Ediciones Era.

Furtado, C. 1954. The Brazilian economy: a contribution to the analysis of its development. Río de Janeiro: Editora a Noite.

Furtado, C. 1967. Teoría y política del desarrollo económico. México: Siglo XXI.

Furtado, C. 1969. La economía latinoamericana. México: Siglo XXI.

Lavoie, M. 2009. Introduction to post-Keynesian economics. New York: Palgrave Macmillan.

McLure, M. 2001. Pareto, economics and society. London and New York: Routledge.

Marini, R.M. 1974. Subdesarrollo y revolución. México: Siglo Veintiuno Editores.

Perroux, F. 1957. Structural inflation and the economic function of wages: the French example, pp. 251263. En: J.T. Dunlop. The theory of wage determination. London: Macmillan.

Prebisch, R. 1952. Discursos, declaraciones y documentos 1952-1963, vol.1. Santiago: CEPAL.

Prebisch, R. 1993. Obras 1919-1948, vol. IV. Buenos Aires: Fundación Raúl Prebisch.

Sotelo, A. 2014. Latin America: dependency and super-exploitation. Critical Sociology 40(4): 539-549. doi: 10.1177/0896920513479616.

Sunkel, O. 1991. El desarrollo desde dentro. Un enfoque neoestructuralista para América Latina. México: FCE.

Tavares, M.C. 1964. Auge y declinación del proceso de sustitución de importaciones en el Brasil. Economic Bulletin for Latin America 9(1): 1-62. http://repositorio.cepal.org/handle/11362/10009

Recibido el 5 Oct 2016

Aceptado el 14 Dic 2016 